\title{
Comments
}

\section{SEQUEL RIGHTS IN THE LAW OF LITERARY PROPERTY*}

The sequel involves a creator's re-use of his principal and secondary characters in new situations. ${ }^{1}$ Its importance in the modern literary and entertainment world is indicated by its extensive use in books, periodicals, and especially television. ${ }^{2}$ The value of an author's interest in his fictional characters and sequel is well recognized in the trade, as is demonstrated by the fact that his interests are often expressly protected by contract. ${ }^{3}$ But in the absence of contract, the law is confused and often inadequate because the law involving intellectual property has not kept pace with the demands of the mid-twentieth century literary and entertainment business. ${ }^{4}$ In part, this confusion results from the interplay of copyright, trade-mark, and unfair competition principles. But perhaps the real blame can be attributed to a fifty-year-old copyright law ${ }^{5}$ that is not flexible enough to guarantee fully to the modern anthor the fruits of his endeavor. ${ }^{b}$

It is the purpose of this Comment to discuss the protection given to the author's sequel rights by the laws of unfair competition, trade-mark, and copyright. The economic value of the sequel lies in the author's right to present a particular fictional character to the public more than once. This Comment, therefore, will proceed by analyzing the protection the law affords the author's fictional character, which may be divided into three general, but often overlapping, categories: (1) the name; (2) the physical appearance (where he appears in one of the visual media); and (3) the "fictional core," i.e., the essence of the character, apart from his name and/or appearance, which identifies him as a distinct fictional entity.

\section{$I$ \\ NAME}

Usually a character in a sequel has the same name as he had in the original work. The name of a character may comprise in whole or in part the title of the

* This paper, in substantially the same form, will be entered in the Nathan Burkan Memorial Competition, sponsored by the American Society of Composers, Authors and Publishers.

1 Wincor, Some Trademark Refiections Upon Dramatic Sequel Rights, 44 Tradearark REP. 1273 (1954); Kellman, The Legal Protection of Fictional Characters, 25 BRookLXN L. REv. 3 (1958).

2 Variety, June 22, 1960, p.36; Variety, July 13, 1960, pp.36-38.

3 Screen Writers contract, negotiated between Writers Guild of America and the Association of Motion Picture Producers, discussed in Variety, June 22, 1960, p. 4; WrITERs GuInd of Adierica, Summiarx of 1960 Television Fird Agreement 3 (1960). When an author sells rights in his book to the motion picture industry, it is frequently provided that the assignee or licensee will not change distinctive traits of any well established characters. Colton, Contracts in the Entertainment and Literary Fields, 1953 Copyright Problems Analyzed 137, 147 (1953) ; Rothenberg, Copyright Considerations in Purchasing Motion Pictures for Television Distribution, 7 Bur.. Copyrigrt Soc. 133, 135 (1960).

4 Burton, Business Practices in the Copyright Field, in Seven Copyriget Problears ANALYZED 87, 116 (1952).

517 U.S.C. (1959).

6 Henn, Current Developments in Copyright Law, 7 Bunx. Copyright Soc. 3, 4-5 (1959); Laskin, All Rights Unreserved: The Author's Lost Property in Publishing and Entertainment, in Copyriget Law Sympostuar Number Seven 91 (1956). 
work and, in the audio-visual arts, may be identical to the firm name of his owners.

When the character's name appears in the title or is the title of the work in which he appears, the author's interest in the name cannot be protected under the copyright law. A copyright of an author's work does not cover the title, ${ }^{7}$ and a title itself is not a proper subject for a statutory ${ }^{8}$ or common law ${ }^{9}$ copyright. This result is sound because originality is a prerequisite for a copyright, ${ }^{10}$ and there can be little original literary work in the formation of a title.11

It is through the interrelated theories of trade-mark and unfair competition that the courts now protect an author's interest in his title. Earkier judicial statements $^{12}$ that there could be no registration of a title as a trade-mark no longer represent the law, for today a title is a valid subject for registration ${ }^{13}$ on the Principal Register. ${ }^{14}$ The Trade-Mark Act does deny registration to a mark that is "primarily merely a surname," only to the surname of a nonfictional person. ${ }^{16}$ Therefore, the act should not bar title registration where the name of a fictional character appears in the title.

But whether or not it is registered or registerable as a trade-mark, the title, of a fictional work may also be protected from appropriation under unfair competition laws. ${ }^{17}$ The gist of unfair competition is generally said to be a "palming off" of one's product as that of the originator or getting a "free ride" on the originator's established reputation. ${ }^{18}$ Confusion in the public mind between the product of the

7 The Lone Ranger, Inc. v. Cox, 39 F. Supp. 487,490 (W.D.S.C. 1941), rev'd on a finding of unfair competition, 124 F.2d 650 (4th Cir. 1942).

8 Oxford Book Co. v. College Entrance Book Co., 98 F.2d 688 (2d Cir. 1938); Warner Bros. Pictures v. Majestic Pictures Corp., 70 F.2d 310 (2d Cir. 1934); Patten v. Superior Talking Pictures, 8 F. Supp. 196 (S.D.N.Y. 1934).

8 Paramore v. Mack Sennett, Inc., 9 F.2d 66 (S.D. Cal.1925) ; 2 Nars, UNFaIR CourpeTITION AND Trade-Maris 892 (4th ed. 1947).

10 Plotkin v. National Comics Publications, Inc., 217 F.2d 332 (2d Cir. 1954); Alfred Bell \& Co. v. Catalda Fine Arts, Inc., 191 F.2d 99 (2d Cir. 1951); Yankwich, Originality in the Law of Intellectual Property, 11 F.R.D. 457 (1952).

11 Copinoer \& Skone JaMes, Copyrout 87 (9th ed. 1958). The courts have also interpreted a title to be an idea, which is uniformly held not to be a subject of copyright. U.S. Copyright Offtce, The Meantng of 'Writnigs' in the Copyrught Clause of the ConstiTUTION 104-05 (1960).

12 Black v. Ehrich, 44 Fed. 793 (C.C.S.D.N.Y.1891) ; Hopkins Amusement Co. v. Frohman, 202 III. 541,67 N.E. 391 (1903).

13 Crime Confessions, Inc. v. Fawcett, Inc., 31 C.C.P.A. (Patents) 760, 139 F.2d 499 (1943); New York Herald v. Star Co., 146 Fed. 204 (C.C.S.D.IV.Y.1906), aff'd per croriam, 146 Fed. 1023 (2d Cir. 1906); The Lone Ranger, Inc. v. M. A. Henry, Inc., 100 U.S.P.Q. 33 (Comm'r of Patents 1953); In re The Page Company, 8 Tradeasark Rer. 27 (C.C.A.D.C. 1917).

1160 Stat. 427 (1946), 15 U.S.C. \& 1051 (1959).

1560 Stat. 428 (1946), 15 U.S.C. $\$ 1052(\mathrm{e})(3)$ (1959). In re Sawyer Electrical Mfg. Co., 32 C.C.P.A. (Patents) 740, 144 F.2d 893 (1944) (construing Trade-Mark Act of 1905, ch. 592, § $5 ; 33$ Stat. 725).

16 Newbury, Protection of Comic Strips, in Copyright Law Sympostum Number Eight 37,40 (1957).

17 Harris v. Blackwell, 10 Trademark Rep. 119 (N.Y.Sup. Ct. 1920); 2 Nars, op. cil. supra note 9, at 905.

18 Under the "free ride" doctrine equity will enjoin a defendant's activities "where the apparent purpose is to reap where one has not sown, or to gather where one has not planted, or to build upon or profit from, the name, reputation, good will or work of another." National Design Center, Inc. v. 53d St. Design Centre, Inc., 125 U.S.P.Q. 596, 597 (N.Y. Sup. Ct. 1960). See also International News Service v. Associated Press, 248 U.S. 215 (1918); Axelbank v. Rony, 277 F.2d 314 (9th Cir. 1960); Hopkins Amusement Co. v. Frohman, 202 Ill. 541, 61 N.E. 391 (1903); Oberst, Use of the Doctrine of Unfair Competition to Supplement Copyright in the Protection of Literary and Musical Property, 29 Ky. L.J. 271,274 (1941). 
originator and that of the pirate is a requisite to using unfair competition in title protection cases. ${ }^{19}$ Whether or not public confusion exists in any given case depends upon whether the original title has acquired a secondary meaning, i.e., whether the title is clearly identified by the public with its source. ${ }^{20}$ When a particular title has acquired a secondary meaning, its appropriation will be enjoined ${ }^{21}$ whether or not that title could be exclusively appropriated as a trade-mark. ${ }^{22}$ For example, when Walt Disney used the title "Alice in Wonderland," which is in the public domain and therefore incapable of protection by copyright or trade-mark, he was unable to enjoin a showing of a competitor's motion picture of the same name in an unfair competition action because the Disney "Alice" had not acquired a secondary meaning. ${ }^{23}$

In hiterary property cases some courts have confused and merged the concepts of copyright and unfair competition. ${ }^{24}$ For example, it is sometimes said that there must be a copyright on the work to protect its title against unfair competition. ${ }^{25}$ In spite of these statements, the law against unfair competition exists independently of the copyright law; the presence or absence of a copyright or of a copyrightable work should not affect the court's ability to protect the title from unfair competition. Thus, it has been held that a title that is clearly identified in the public mind with its source cannot be appropriated either during ${ }^{28}$ or after ${ }^{27}$ the term of a copyright.

10 Gardella v. Log Cabin Products Co., 89 F.2d 891 (2d Cir. 1937) ; Lone Ranger, Inc. v. Currey, 79 F. Supp. 190 (M.D. Pa. 1948) ; Chaplin v. Amador, 93 Cal. App. 359, 269 Pac. 544 (1928); Munro v. Tousey, 129 N.Y. 38, 29 N.E. 9 (Ct. App. 1891), aff'd, 129 N.Y. 619, 29 N.E. 10 (1891) ; Comment, 21 Albany L. ReV. 185, 194 (1957).

20 Becker v. Loews, Inc., 133 F.2d 889, 893 (7th Cir. 1943); Johnston v. 20th CenturyFox Film Corp., 82 Cal. App. 2d 796, 810, 187 P.2d 474, 483 (1947); 1 Niss, op. cit. supra note 9 , at 154 .

21 Photoplay Pub. Co. v. La Verne Pub. Co., 269 Fed. 730 (3d Cir. 1921); Patten v. Superior Talking Pictures, Inc., 8 F. Supp. 196 (S.D.N.Y. 1934); Harris v. Blackwell, 10 TradE2IARK REP. 119 (N.Y. Sup. Ct. 1920). Injunction denied where plaintiff's title had not acquired a secondary meaning: Becker v. Loevs, Inc., 133 F.2d 889 (7th Cir. 1943); Manners v. Triangle Filn Corp., 247 Fed. 301 (2d Cir. 1917); Bowers v. Krugel, 8 Trademark ReP. 400 (N.Y. Sup. Ct. 1918).

22 "It [secondary meaning] contemplates that a word or phrase originally, and in that sense primarily, incapable of exclusive appropriation with reference to an article on the market, because geographically or otherwise descriptive, might nevertheless have been used so long and so exclusively by one producer with reference to his article that, in the trade and to that branch of the purchasing public, the word or phrase had come to mean that the article was his product; in other words, had come to be, to them, his trade-mark." G. \& C. Merriam Co. v. Saalfield, 198 Fed. 369, 373 (6th Cir. 1912). See also Photoplay Pub. Co. v. La Verne Pub. Co., 269 Fed. 730 (3d Cir. 1921); Walt Disney Productions v. Souvaine Selective Pictures, Inc., 98 F. Supp. 774 (S.D.N.Y. 1951), af'd per curiam, 198 F.2d 856 (2d Cir, 1951).

23 Walt Disney Productions v. Souvaine Selective Pictures, Inc., stspra note 22.

24 See, e.g., Archie Comic Publications, Inc. v. American News Co., 125 N.Y.S.2d 919 (Sup. Ct. 1953); Street \& Smith Publications, Inc. v. Phantoun Detective Inc., 148 Misc. 897, 266 N.Y.S. 26 (Sup. Ct. 1933); 1 Caliman, Unfatr Competition and Trade-Mark 277 (2d ed. 1950).

25 Paramore v. Mack Sennett, 9 F.2d 66, 67 (S.D. Cal. 1925); Patten v. Superior Talking Pictures, 8 F. Supp. 196, 197 (S.D.N.Y. 1934) ; Note, 68 HARv. L. REv. 349, 353 (1954).

26 Patten v. Superior Talking Pictures, 8 F. Supp. 196 (S.D.N.Y. 1934).

27 Ogilvie v. G.\& C. Merriam Co., 149 Fed. 858 (C.C. Mass. 1907), modified, 159 Fed. 638 (1st Cir. 1908) ; G.\& C. Merriain Co. v. Saalfield, 198 Fed. 369 (6th Cir. 1912). See also Estes v. Williams, 21 Fed. 189 (C.C.S.D.N.Y. 1884); 3 Carraran, Unfatr Competition and TradeMARK 1173 (2d ed. 1950). 
When the character name is not included within the title, copyrighting the work will not provide the author with a property interest in the name. ${ }^{28}$ But a character's name will be protected from appropriation under principles of unfair competition where the defendant "palms off" his character as that of the plaintiff or where the plaintiff's character has acquired a secondary meaning. ${ }^{29}$

Whether included in the title of the work or not, the character's name may be identical with the firm name of the originator. The courts have long recognized a "man's right to enjoy the good repute which he has earned," and accordingly they have used principles of unfair competition to protect an originator's "right to the identity which he has established for himself among his fellows and in the public eye."30 Thus, the Commissioner of Patents has been upheld in refusing to register "Amos-n-Andy" for a workshirt trade-mark because of the confusing similarity with the entertainment copartnership of the same name. ${ }^{31}$ Insofar as a character-firm name identifies and distinguishes an entertainment service, such a name should be registerable as a service mark..$^{32}$

\section{II}

\section{PHYSICAI APPEARANCE}

The author's right to re-use a character who appears in a cartoon or conic strip is clearly protected. It is well established that a cartoon character is a valid subject for a statutory copyright. ${ }^{33}$ Thus, the courts have found infringement of a copyrighted cartoon where the character's physical appearance was appropriated

28 Warner, Radio aNd Television Rights 234 (1953).

29 Wiley v. National Broadcasting Co., 31 F.Supp. 568 (IN.D. Cal. 1940) (injunction denied, no secondary meaning); Prouty v. National Broadcasting Co., 26 F. Supp. 265 (D. Mass. 1939) ("Stella Dallas"); Curtiss Candy Co. v. Canner, 17 Trademark Rep. 286 (C.C. III. 1927).

The Nick Carter case, Atlas Mrg. Co. v. Street \& Smith, 204 Fed. 398 (8th Cir. 1913), is contrary authority but can no longer be considered to represent the law. In that case the court refused to enjoin the showing of a motion picture which had appropriated from the plaintiff's detective magazine the naune "Nick Carter," a fictional character whose exploits were portrayed in the notion picture. Since the plaintiff was selling magazines and the defendant, motion pictures, the court reasoned that competition was not present and refused to issue an injunction. This reasoning is now rendered obsolete by the Lanham Act, 60 Stat. 427 (1946), 15 U.S.C. $\$ \$ 1051-1127$ (1959) and by the nodern common law of unfair competition, which no longer requires competition between economic enterprises. Hill v. Whalen \& Martell, Inc., 220 Fed. 359 (S.D.N.Y. 1914) ; Fanous Funnies v. Famous Funn Family, 37 F. Supp. 903 (S.D.N.Y. 1941); Prouty v. National Broadcasting Co., 26 F. Supp. 265 (D. Mass. 1939); 2 Nms, op. cit. supra note 9, at 1194-1206; 1 Caltaran, Unfatr Competition aNd Trade-MaRK 95-96 (2d ed. 1950).

30 Premier-Pabst Corp. v. Elm City Brewing Co., 9 F. Supp. 754, 758 (D. Conn. 1935). See also The Lone Ranger, Inc. v. Currey, 79 F. Supp. 190 (M.D.Pa. 1948).

31 Feldinan v. Amos and Andy, 21 C.C.P.A. (Patents) 823, 68 F.2d 746 (1934). See also Van Dover v. R.K.O. Radio Pictures, Inc., 50 U.S.P.Q. 348 (N.D.Ill. 1941); WaRNER, RAdro aNd TELEvision Rigits 1018 (1953).

3260 Stat. 429, 443 (1946), 15 U.S.C. $\$ \S 1053,1127$ (1959). Whereas a trade-mark identifies and distinguishes goods, a service-mark "identifies and distinguishes services and includes various distinctive features of advertising which identify a service." Robert, Commentary on the Lanham Trade-NIark Act, in 15 U.S.C.A. (\$§ 81-1113) 265, 269 (1948).

33 Grant v. Kellogg Co., 58 F. Supp. 48 (S.D.N.Y. 1944) ("Snap, Crackle, and Pop" of Rice Krispie fame) ; Kellman, The Legal Protection of Fictional Characters, 25 Brookryn L. REv. 3, 10 (1958). See also Rushton v. Vitale, 218 F.2d 434 (2d Cir. 1955) ("Zippy" a chinpanze froin a television show). 
by another comic book, ${ }^{34}$ a stage production, ${ }^{35}$ or a doll manufacturer..$^{36}$

It has been said that the cartoonist "probably enjoys broader all around legal protection than any other person in the law,"37 but the use of a copyright to protect the physical appearance of a cartoon character from appropriation does have limitations, as was borne out by Superman's battle against Wonderman in Detective Comics, Inc. v. Bruns Publications, Inc. ${ }^{38}$ There, a federal district court issued a permanent injunction "forbidding the further publication by the defendant ... of its cartoon character 'Wonderman,' in such a form as will make that cartoon character trespass in any respect on the plaintiff's cartoon character 'Superman.' "139 On appeal, the Second Circuit agreed that if Superman was inore than a "general type" he was the subject of a copyright; but even then, said the court, the plaintiff was "not entitled to a monopoly of the mere character of a 'Superman' who is a blessing to mankind." 40 The "too sweeping" decree of the district court was modified to prevent "defendant's 'Wonderman' from portraying any of the feats of strength or powers performed by 'Superman' or closely imitating his costume or appearance in any feat whatever." 41 This language was later interpreted by the same court as limiting "the copyright to the specific exploits of 'Superman' as each picture portrayed them." 42 Thus has the Second Circuit attempted to limit the copyright protection of cartoon characters.

The physical appearance of cartoon characters may also be protected by registration under the Trade-Mark Act. ${ }^{43}$ Infringement has been found when there is a likelihood of public confusion as to the source of the two characters. In Lone Ranger, Inc. v. Currey, ${ }^{44}$ the defendant, a rodeo and circus performer, was enjoined by a federal district court from "imitating any or all of the distinctive and dominant characteristics of 'The Lone Ranger' program, the cowboy garb and mask, the white horse named Silver ... the silver studded trappings and the two guns worn by 'The Lone Ranger." "45 The court also enjoined the defendant from using "the unique call 'Hi Yo Silver' and 'Hi Yo Silver Away." "46 It is not clear whether the ground for the decision was unfair competition or infringement of The Lone Ranger's registered trade-mark, but either would seem to have been applicable.

Where a cartoon character's physical appearance has acquired a secondary meaning, the law of unfair competition may be used to prevent its unauthorized

${ }^{44}$ Detective Comics, Inc. v. Bruns Publications, Inc, 28 F. Supp. 399 (S.D.N.Y. 1939), af'd as modified, 111 F.2d 432 (2d Cir. 1940) ("Superman"). See also Plotkin v. National Comic Publications, 217 F.2d 332 (2d Cir. 1954) ("Atom man" not original and therefore no infringement by "Superman").

35 Hill v. Whalen \& Martell, Inc., 220 Fed. 359 (S.D.N.Y. 1914) ("Mutt \& Jeff"). See also Empire City Amusement v. Wilton, 134 Fed. 132 (C.C. Mass. 1903) ("Alphonse \& Gaston"). 36 Fleischer Studios, Inc., v. Freundlich, 73 F.2d 276 (2d Cir. 1934) ("Spark Plug").

37 Derenberg, Copyright No-Man's Land: Fringe Rights in Literary and Artistic Property, in 1953 Copyright Problemis ANALyzed 215, 222 (1953).

3828 F. Supp. 399 (S.D.N.Y. 1939), aff'd as modified, 111 F.2d 432 (2d Cir. 1940).

3928 F. Supp, at 401.

10111 F.2d at 434 .

41 Ibid.

42 National Comics Publications, Inc. v. Fawcett Publications, Inc., 191 F.2d 594, 600 (2d Cir. 1951).

43 "The Lone Ranger," The Lone Ranger, Inc. v. M. A. Henry Co., Inc., 100 U.S.P.Q. 33 (Comm'r of Patents 1953) ; "Sooky," Ex parte Percy L. Crosby, 16 U.S.P.Q. 345 (Comm'r of Patents 1933); "Mutt \& Jeff," Cancellation No. 344 (Star Co. v. Fisher) discussed in Ex parte Percy L. Crosby, supra at 346.

4479 F. Supp. 190 (M.D. Pa. 1948).

45 Id. at 195 .

46 Ibid. 
use. Thus, in Fisher v. Star Co., ${ }^{47}$ the Mutt and Jeff case, the New York Court of Appeals held that these characters "have been so connected with plaintiff as their originator and author that the use by another of new cartoons exploiting the characters 'Mutt and Jeff' would be unfair to the public and to the plaintiff."48 And in Chaplin v. Amador, ${ }^{49}$ the California District Court of Appeals affirmed an injunction preventing the defendant, Charles Aplin, from fraudulently imitating the Little Tramp, a character "portrayed by Charles Chaplin for so long and with such artistry, that he has becoine well known all over the world in this character." The court expressly stated that the cause of action did not depend on any "right to the exclusive use of the role, garb, and nnannerism," but that it was based upon injury to the plaintiff and deception practiced upon the public..1

Therefore, insofar as the value of sequel riglits lies in a re-use of the plyysical manifestation of a character who appears in a comic strip or cartoon, the originator is well protected by the laws of copyright, trade-mark, and unfair competition..$^{52}$ But where a motion picture, stage, or television character is involved, the physical appearance of the character and the performance of the artist are difficult, if not impossible, to separate. A copyright is not available in this country to protect an artist's performance, ${ }^{53}$ but if the artist's character is distinctive and known to the public it might be subject to registration as a service mark, ${ }^{54}$ and in any event it could be protected under principles of unfair competition. ${ }^{.5}$

III

FICTIONAL CORE

\section{A. Trade-Mark}

Whereas a trade-mark is available to an author who wishes to protect the physical appearance of a character ${ }^{58}$ or to protect a name that appears in a title, ${ }^{67}$

47231 N.Y. 414, 132 N.E. 133 (1921). But see Outcalt v. New York Herald, 146 Fed. 205 (C.C.S.D.N.Y.1906).

48231 N.Y. at 433,132 N.E. at 139.

4993 Cal. App. 358, 269 Pac. 544 (1928); 2 So. CaL. L. Rev. 194 (1928).

5093 Cal. App. at 360, 269 Pac. at 545. In Jones v. Republic Pictures, 112 F.2d 672 (9th Cir. 1940) the Chaplin case was made the basis of a "reverse character appropriation" action. The complaint was that the Lone Ranger appearing in defendant's motion picture serial copied the mannerisms of plaintiff Buck Jones and his horse Silver. The reported case involved a removal question and the court did not pass on the merits.

B1 93 Cal. App. at 363, 269 Pac. at 546.

52 Kellman, supra note 33, at 10-11.

63 Universal Pictures Co. v. Harold Lloyd Corp., 162 F.2d 354 (9th Cir. 1947); Chappell \& Co. v. Fields, 210 Fed. 864 (2d Cir. 1914); Savage v. Hoffunan, 159 Fed. 584 (C.C.S.D.N.X. 1908); Waring v. W.D.A.S. Broadcasting Station, 327 Pa. 433, 437-38, 194 At1. 631, 633 (1937).

S4 60 Stat. 427, 443 (1946), 15 U.S.C. $\$ \$ 1051,1127$ (1959). It is not yet established whether the service mark expands traditional trade-ınark principles. Compare Warner, The Applicability of the Lanham Trade-Mark Act to Radio and Television Service Marks, 23 So. Cax. L. REv. 309, 324-25 (1950) and Wincor, Some Trademark Reflections Upon Dramatic Sequel Rights, 44 Trademark Rep. 1273 (1954) with Derenberg, The Lanham Trade-Mark Act of 1946, Practical Effects and Experiences After One Year's Administration, 38 Trademark Rep. 831, 845 (1948). But see Wincor, The Seven Basic Program Properties, 47 Trademark REP. 440, 445 (1957), who reports that Jackie Gleason was able to register as service marks his "away we go" phrase and pose.

53 Waring v. W.D.A.S. Broadcasting Station, 327 Pa. 433, 194 Atl. 631 (1937); Warner, RAdio AND TEIEVISION Rights 1028-29 (1953).

56 See text at note 43 supra.

57 See text at notes 12-16 supra. 
it offers no means of legal redress when the fictional essence of a character is pirated. The function of the trade-mark is identification, and as a part of the law of unfair competition it recognizes that "a man who [has] come to be identified by the public for specific goods through some specific association [is] entitled to the exclusive use of such means of identification." ${ }^{158} \mathrm{~A}$ trade-mark does not protect the character, but that which the character identifies. ${ }^{59}$ Thus, although a trade-mark is generally available to protect the name or appearance of a character, it does not protect against an appropriation of the character itself..$^{60}$

\section{B. Unfair Competition}

General principles of unfair competition have been invoked where a pirate's action dilutes the public interest $t^{61}$ or where he holds out an inferior copy which results in damage to the originator's reputation. ${ }^{62}$ The author whose fictional character has been appropriated is also damaged in the same inanner, but two opinions ${ }^{63}$ have raised serious questions as to the efficacy of an unfair competition action to protect his interests. In National Comics Publications, Inc. v. Fawcett Publications, Inc., ${ }^{\text {,4 }}$ Superman claimed that Captain Marvel unfairly competed with him through character appropriation. Judge Learned Hand, holding for the defendant on this point, said that for unfair competition there must be public confusion,

and that presupposes, not only that the mark has become associated with the orfner as the source of the goods, but that this association is an inducement to deal with the owner. In the case of these silly pictures nobody cares who is the producer-least of all, children who are the chief readers-; the 'strips' sell because they amuse and please, and they amuse and please because they are what they are, not because they come from 'Detective.'6s

Thus, where a fictional character can gain popularity without public identification as to source, the National Comics case would seem to bar the use of general principles of unfair competition to prevent character piracy. ${ }^{68}$

In the second case, Warner Bros. Pictures v. Columbia Broadcasting System, ${ }^{67}$ the court held that the use of the character Sam Spade in a radio series did not unfairly compete with the motion picture "Maltese Falcon" which had as its principal character the same Sam Spade. The court said there could be unfair compe-

58 Premier-Pabst Corp. v. Elm City Brewing Co., 9 F. Supp. 754, 758 (D. Conn. 1935).

58 Ex parte Carter Publications, Ine., 92 U.S.P.Q. 251, 93 U.S.P.Q. 104-06 (Comm'r of Patents 1952); Derenberg, Copyright No-Man's Land: Fringe Rights in Literary and Artistic Property, in 1953 Copyright Probiems Analyzed 215, 221-24 (1953). But see Curtiss Candy Co. v. Canner, 17 Trademark Rep. 286 (C.C. Ill. 1927).

60 Kellman, supra note 33, at 5 ; Note, 68 Harv. L. Rev. 349, 350 (1954).

61 See Hill v. Whalen \& Martell, Inc., 220 Fed. 359 (S.D.N.Y. 1914); Fisher v. Star Co., 221 N.Y. 414, 132 N.E. 133,139 (1921).

62 See Prouty v. National Broadcasting Co., 26 F. Supp. 265 (D. Mass. 1939). In a trademark case Judge Learned Hand has said that the infringer "borrows the owner's reputation, whose quality no longer lies within his own control." Yale Electric Corp. v. Robertson, 26 F.2d 972, 974 (2d Cir. 1928). See also The Lone Ranger, Inc. v. Currey, 79 F. Supp. 190, 194 (M.D.Pa.1948), where the defendant, appearing in a circus parade as the Lone Ranger, "so unmercifully beat his horse that protests were made by the Humane Society."

${ }^{83}$ National Comics Publications, Inc. v. Fawcett Publications, Inc., 191 F.2d 594 (2d Cir. 1951); Warner Bros. Pictures v. Columbia Broadcasting System, 216 F.2d 945 (9th Cir. 1954).

64 National Comics Publications, Inc. v. Fawcett Publications, Inc., supra note 63.

65 Id. at 603.

${ }^{86}$ See Note, 68 HaRv. L. REv. 349, 355 (1954).

87216 F.2d 945 (9th Cir. 1954). 
tition only if the public was deceived or if the defendant's character was "used in such a manner as to cause the Falcon to be materially lessened in its commercial worth by degrading or cheapening" the characters..$^{88}$ One author lias concluded that this case leaves "it open to anyone to appropriate a character for sequel purposes, providing only that the characters thus appropriated are tastefully treated in the unauthorized sequel so that no claim of degrading or cheapening can be made." ${ }^{\prime \prime 9}$ Indeed, after the Maltese Falcon case the general principles of unfair competition would not seem to afford much protection to the fictional core of an author's character.

The judicial contraction of the scope of unfair competition in the National Comics and Maltese Falcon cases seems sound. Protection of fictional characters, divorced from considerations of name and physical appearance, comes dangerously close to the protection of ideas. If fictional characters are to be protected by a monopoly granted to the creator, it should be through the copyright law, a statutory monopoly limited to fifty-six years, ${ }^{70}$ and not through the law of unfair competition, which lias no defirite terminal point. ${ }^{71}$

\title{
C. Copyright
}

The object of the copyriglit law is to "promote the Progress of Science and useful Arts, by securing for himited Times to Authors and Inventors the exclusive Right to their respective Writings and Discoveries."72 Recognizing the monopolistic nature of a copyright, the courts have consistently balanced the author's interest in securing the fruits of lis endeavor against the public's interest in not having certain aspects of literary expression withdrawn from the public domain. One line drawn by the courts has been between form and ideas. Accordingly, it has been said that a copyright protects not an idea but the expression of an idea. ${ }^{73}$ The policy behind the courts' drawing this line has been well stated by Justice Traynor of the California Supreme Court:

\begin{abstract}
What men forge out of these ideas with skill, industry, and imagination, into concrete forms uniquely their own, the law protects as private property. It gives the special form the stamp of recognition; it does so to stimulate creative activity. It does something more to stimulate creative activity: it assures all men free utilization of abstract ideas in the process of crystallizing them in fresb forms. For creativeness thrives on freedom; men find new implications in old ideas when they range with open minds through open fields. ...

It would be ironic if copyright law, designed to encourage creative activity, became the instrument of its destruction. The very function of creative activity is to keep the common field in continuous germination; it is not for copyright law to render it barren by a succession of enclosures denying access to those who would cultivate it. . . . 74
\end{abstract}

In extending the protection of copyright to the charatcer's fictional core, the courts have no doubt been troubled with this form-idea distinction, and insofar as a

68 Id. at 951 .

69 Nimmer, Copyright 1955, 43 CAIIF. L. Rev. 791, 795 (1955).

7017 U.S.C. \& 24 (1959).

71 Note, 68 HARV. L. REV. 349, 355-56 (1954).

72 U.S. Corst. art. I, § 8, cl. 8.

73 Holmes v. Hurst, 174 U.S. 82, 86 (1899); Dymow v. Bolton, 11 F.2d 690, 691 (2d Cir. 1926); Fendler v. Morosco, 253 N.Y. 281, 171 N.E. 56 (1930); Tutelman v. Stokowski, 44 U.S.P.Q. 47 ( $\mathrm{Pa}$. Ct. C.P. 1939); Wehster, Protecting Things Valuable-Ideas, in CopYRIGHT LAw Straposium Number Frve 158, 165 (1954).

74 Stanley v. Columbia Broadcasting System, 35 Cal.2d 653, 673, 221 P.2d 73, 84 (1950) (dissent). See also Eichel v. Marcin, 241 Fed. 404, 408 (S.D.N.Y. 1913). 
character can be called an idea the courts have refused to protect his creator under the copyright law. ${ }^{75}$ Thus, a copyright on the literary work wherein the character appears has been held not to extend protection to the character. ${ }^{76}$

In the leading Maltese Falcon case, ${ }^{77}$ the Ninth Circuit for all practical purposes removed a character's fictional core from the aegis of copyright. Although the case was decided upon an interpretation of the author's contract with his assignee, ${ }^{78}$ the court considered the question of whether or not the characters could be copyrighted and said in a dictum, "It is conceivable that the character really constitutes the story being told, but if the character is only the chessman in the game of telling the story he is not within the area of protection afforded by the copyright. ... [Here] the characters were vehicles for the story told, and the vehicles did not go with the sale of the story." "Since it is difficult to imagine a case where the character, whether he be as distinctive as Sherlock Holmes or Cyrano de Bergerac, will not be the "chessman in the game of telling the story," the court's statement in the Maltese Falcon case would seem "almost completely [to] exclude characters from statutory copyright protection." the court made this statement in an apparent attempt to bolster the sequel rights of the author mediately before it. Recognizing that "the practice of writers to compose sequels to stories is old," the court reasoned that had Congress "intended that a sale of a right to publish a copyrighted story would foreclose the author's use of its characters in subsequent works for the life of the copyright, it would seem Congress would have made specific provision therefor."81 It is submitted that this problem would be best solved by a re-examination of copyright assignment and divisibility, ${ }^{82}$ and not by refusing to extend the copyright protection to fictional characters.

The common law copyright will likewise be of no avail to the author who wishes to protect his fictional characters. For sequel purposes the fictional char-

75 This view was expressed by an English court when it said: "If, for instance we found a modern playright creating a character as distinctive and remarkable as Falstaff, or as Tartuffe, or (to come to a recent clasic) as Sherlock Holmes, would it be an infringement if another writer, one of the servile flock of imitators, were to borrow the idea and make use of an obvious copy of the original ? I should hesitate a long time before I came to such a conclusion." Kelley v. Cinema Houses Ltd. (1932), in MacGillivray's Copyright Cases (1928-35) 362.

76 Pelligrini v. Allegrini, 2 F.2d 610 (E.D. Pa. 1924); Tralins v. Kaiser Alum. \& Chem. Corp., 160 F. Supp. 511 (D.Md. 1958); Burtis v. International Pictures Co., 40 Cal. 2d 823, 256 P.2d 933 (1953); Kelley v. Cinema Houses Ltd., supra note 75.

77 Warner Bros. Pictures v. Columbia Broadcasting System, 216 F.2d 945 (9th Cir. 1954). 78 "We are of the opinion that since the use of characters and character names are nowhere specifically mentioned in the agreements, but that other items, including the title, "The Maltese Falcon', and their use are specifically mentioned as being granted, that the character rights with the names cannot be held to be within the grants." Id. at 949. The court supported this interpretation by observing that detective fiction writers often use the "leading characters with their names and individualisms from one story into succeeding stories." Ibid. See also Gillette v. Stoll Film Co., 120 Misc. 850, 200 N.Y.S. 787 (Sup.Ct. 1922) ("Sherlock Holmes") ; Note, 68 HaRv. L. REv. 349, 361 (1954). 1954).

$7^{9}$ Warner Bros. Pictures v. Columbia Broadcasting System, 216 F.2d 945, 950 (9th Cir.

80 Nimmer, Copyright 1955, 43 CAcIF. L. REv. 791, 794 (1955).

81 Warner Bros. Pictures v. Columbia Broadcasting System, 216 F.2d 945, 950 (1954).

82 Statutory recognition of the trade practice of dividing up the copyright into a packet of rights, as opposed to the now prevailing indivisible copyright concept, could give greater definiteness as to the extent of an assignment or grant. Kaminstein, Divisibility of Copyrights, U.S. Copyright Office, General Revision of Copyright Law, Study No. 4 (1958). 
acter becomes commercially valuable only after he has attained some notoriety in the public eye, i.e., after publication. A general publication is said to be a dedication to the public that is an abandonment of any common law right to a copyright. ${ }^{83}$ Thereafter the author's rights are defined solely by statute, ${ }^{84}$ for "when the statutory right begins the common-law right ends." 85

The district court in the Maltese Falcon case, ${ }^{88}$ however, held that the obtaining of a statutory copyright does not divest the author of his common law rights other than the perpetual right to restrict publication. ${ }^{87}$ This "residual rights theory" has been justly criticized as an unwise extension of the common law copyright, ${ }^{88}$ for it would create in the originator a perpetual monopoly and thus be opposed to the limited monopoly created by the copyright statute. ${ }^{89}$ Furthermore, a coexisting system of common law and statutory rights inight hinder saleability of a literary product because of uncertainty as to the scope of the residual rights. ${ }^{.0}$ Thus, if the character is to be protected, it should be through a statutory copyright and not by an extension of common law doctrine. ${ }^{21}$

The statutory copyright, either as it now exists or through ainendment, could be used to protect the "core" of an author's fictional character. One writer has suggested that the copyright law extends not only to the literal content of the work, but also to the "mental content" commumicated, and that when the "mental content" is expressed in concrete form it becomes a part of the work protected by the copyright. ${ }^{22}$ Hence, it is arguable that the "fictional core," i.e., the "mental content," could be protected under the existing statutory copyright scheme. But since distinguishing between "tangible mental content" and "ideas" would be ill adapted for commercial trading, ${ }^{93}$ it is submitted that it would be preferable if the copyright statute were amended to provide recognition of sequel rights through

83 Egner v. E. C. Schirmer Music Co., 139 F.2d 398, 399-400 (1st Cir. 1943); Werckmerster v. American Lithographic Co., 134 Fed. 321, 324 (2d Cir. 1904); Richard J. Cole, Inc. v. Manhattan Modes Company, Inc., 109 U.S.P.Q. 370, 372 (N.Y. Sup. Ct. 1956). But see Fashion Originators Guild v. Federal Trade Comm'n, 114 F.2d 80, 83 (2d Cir. 1940).

8417 U.S.C. (1959).

85 Bobbs-Merrill Co. v. Straus, 210 U.S. 339, 347 (1908). See also National Comics Publications, Inc. v. Fawcett Publications, Inc., 191 F.2d 594, 598 (2d Cir. 1951); Photo Drama Motion Picture Co. v. Social Uplift Film Corp., 220 Fed. 448 (2d Cir. 1915); Loew's Inc. v. Superior Court, 18 Cal.2d 419, 115 P.2d 983 (1941); Donaldson v. Becket, 4 Burr. 2407,

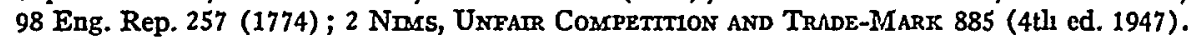
86 Warner Bros. Pictures v. Columbia Broadcasting System, 102 F. Supp. 141 (S.D. Cal. 1951), affd, 216 F.2d 945 (9th Cir. 1954).

87102 F. Supp. at 147.

88 Nimmer, Copyright 1955, 43 CaLrF. L. Rev. 791 (1955); Wauner, Radio and Televiston Rights 233 (1953). The "residual rights" analysis was rejected sub silentio by the Ninth Circuit on appeal. Warner Bros. Pictures v. Columbia Broadcasting System, 216 F.2d 945 (9th Cir. 1954).

${ }^{89}$ See Bobbs-Merrill Co. v. Straus, 210 U.S. 339 (1908); Moore v. Ford Motor Co., 28 F.2d 529, 536 (S.D.N.Y. 1928); Nimmer, supra note 88, at 793; Newbury, Protection of Comic Strips, in Copyricht Law Sysaposius Number Eight 37, 55 (1957).

00 WarNer, Radio aNd TELEviston RigHTS 233-34 (1953).

81 It is likely that the courts would not use the common law copyright to protect fictional characters, reasoning that they are mere ideas and not subject to protection. See, e.g., Kurlan v. Columbia Broadcasting System, 40 Cal.2d 799, 256 P.2d 962 (1953); Burtis v. International Pictures Co., 40 Cal. 2d 823, 256 P.2d 933 (1953).

92 Ebenstein, Introduction, in Rothesserg, Copyruger LAW xV-xx (1956).

93 Wincor, The Severt Basic Program Properties, 47 Trademark Rr:P. 440 (1957). 
protection of the character's fictional core. ${ }^{91}$ Any such amendment should recognize the present rule that there can be no monopoly over a mere type. ${ }^{95}$ Thus, any borrowing of a type should be considered the taking of a mere idea which would not be protectable; in order to be protectable the character would have to be so well developed that he could be said to be "distinctive."

Even under such a copyright statute it is likely that character protection would still be closely related to problems of originality, fair use, and plagiarism, since it is common for courts in searching for piracy to compare the characters appearing in each of the works. ${ }^{97}$ But any test which looks to an examination of characters to find the substantial identity required for infringement will be vague, since the test for infringement has always been vague. ${ }^{88}$ Yet the line between piracy and fair use will have to be drawn no matter how arbitrary it may seem in a particular case. ${ }^{99}$ Moreover, where a certain character-type must exist because the situation requires that type of character, it should still be difficult for the complamant author to meet the demands of originality. ${ }^{100}$ Where the author draws characters from the public domain, his copyright would protect his treatment only if it could be considered original. ${ }^{101}$ As stated by an English court, the author, "to prove his right, must at least establish that he is the author of the character or the idea in some possible sense of the word."102

Such an amendment to the copyright law would effectively protect the author's rights to re-use that character in sequels. This would not be a great change in current copyright thought: titles of works and physical appearances of characters

94 Another suggestion has been to extend the trade-mark law by development of the "program mark." Wincor, Some Trademark Reflections Upon Dramatic Sequel Rights, 44 Trademark Rep. 1273 (1954); Wimcor, The Seven Basic Program Properties, 47 Trademark REP. 440 (1957). The "program mark" analysis seems to apply principally to the character created by performance. Such a doctrine, based upon use and public identification, would expand the rights of the performing artist, but would be undesirable as applied to the fictional character who is not created by performance. See notes 104 and 105 infra.

95 Nichols v. Universal Pictures Corp., 45 F.2d 119 (2d Cir. 1930); Lewys v. O'Neill, 49 F.2d 603 (S.D.N.Y. 1931) ; Weitzenkorn v. Lesser, 40 Cal. 2d 778, 256 P.2d 947 (1953).

${ }^{96}$ Nichols v. Universal Pictures Corp., supra note 95, at 121 ; Burtis v. International Pictures, 40 Cal. 2d 823, 256 P.2d 933 (1953).

97 See, e.g., Harold Lloyd Corp. v. Witner, 65 F.2d 1 (9th Cir. 1933); Rush v. Oursler, 39 F.2d 468 (S.D.N.Y. 1930); Stephens v. Howells Sales Co., 16 F.2d 805 (S.D.N.Y. 1926); Soloman v. R.K.O. Radio Pictures, Inc., 44 F. Supp. 780 (S.DN.Y. 1942); Curwood v. Affiliated Distributors, 283 Fed. 223 (S.D.N.Y. 1922). Judge Yankwich has said that the "substance of originality, so far as dramatic compositions ... are concerned, centers around the sequence of incidents and locale, but more particularly, upon the characterizations through which the story is brought home." Yankwich, Originality in the Law of Intellectual Property, 11 F.R.D. 457,467 (1951).

88 Nichols v. Universal Pictures Corp., 45 F.2d 119, 121 (2d Cir. 1930) ; Dymow v. Bolton, 11 F.2d 690 (2d Cir. 1926); Folsom v. Marsh, 9 Fed. Cas. 342, 348, (No. 4901) (C.C.D. Mass. 1841).

89 Nichols v. Universal Pictures Corp., 45 F.2d 119, 122 (2d Cir. 1930); Peter Pan Fabrics, Inc. v. Martin Weiner Corp., 274 F.2d 487, 489 (2d Cir. 1960).

100 See Collms v. Metro-Goldwyn Pictures Corp., 25 F. Supp. 781 (S.D.N.Y. 1938) ("Test Pilot"); Golding v. R.K.O. Pictures, 35 Cal. 2d 690, 221 P.2d 95 (1950) ("Sea Captain and his Opponent"); Columbia Pictures Corp. v. Krasna, 65 N.Y.S.2d 67 (Sup. Ct. 1946) ("The Family Circle").

101 See Weitzenkorn v. Lesser, 40 Cal. 2d 778, 256 P.2d 947 (1953) ("Tarzan, Jane \& Cheta"); Axelbank v. Rony, 277 F.2d 314 (9th Cir. 1960); Kovacs v. Mutual Broadcasting System, 99 Cal. App. 2d 56, 221 P.2d 108 (1950).

102 Kelley v. Cinema Houses, Ltd. (1932), in Maccrumrvany's Copyriget Cases (1928-35) 369. See also Fisher v. Dillingham, 298 Fed. 145 (2d Cir. 1924). 
would still be protected through trade-mark and unfair competition laws. But rather than extending these concepts, a copyright should be made available to protect the fictional core of the author's character. Unfair competition is vague in its breadth and flexibility, and does not afford the certainty and feeling of ownership desired in commercial transactions. ${ }^{103}$ And any extension of trade-mark to protect the fictional character, where physical appearance and title are not at issue, would raise undesirable problems of duration ${ }^{104}$ and alienability ${ }^{105}$ that would not arise under the statutory copyright law. Since any manner of protection of an author's interest in literary property will limit to some extent similar methods of literary expression, it is submitted that such a monopoly is best granted and controlled by copyright principles.

D. L.A. Kerson

103 Wincor, The Seven Basic Program Properties, 47 Trademark 440 (1957).

104 While the statutory copyright is limited to a maximum of 56 years, 17 U.S.C. $\$ 24$ (1959), trade-mark registration and use can he perpetual, 15 U.S.C. $\$ 1059$ (1959).

105 It has been suggested that under trade-mark law sequel rights may be inalienable. Wincor, Some Trademark Reflections Upon Dramatic Sequel Rights, 44 TradeMark REP. 1273, 1278 (1954). 